\title{
IMPORTANCE OF A MANAGEMENT PLAN IN PROTECTION OF CULTURAL HERITAGE: ISTANBUL HISTORIC PENINSULA CASE
}

\author{
HULYA BERKMEN \\ Department of Urban and Regional Planning, Yildiz Technical University, Turkey
}

\begin{abstract}
Today, while current discussions elaborate topics like integrated urban management strategies; conservation plans; renovation actions and financial mechanisms for these actions; and the development of socially responsible projects, the terms "area management" and "management plan" play an important role in the practice of urban protection and planning in Turkey, as in the rest of the world. Management plans constitute one of the tools used in the planning and application processes and are accepted as a basis for providing a balance between protection, usage, and development. In the most general sense, these plans can be defined as tools that would guide the authorities in protecting and managing the areas, and in applying the decisions to the related institutions, in both today's world and the future. The terms "area management" and "management plan" have been placed on Turkey's agenda with the "World Heritage Convention", to which Turkey became a party in 1983, parallel to the decisions of the World Heritage Centre regarding United Nations Educational Scientific and Cultural Organization "UNESCO" World Heritage Areas. Istanbul's World Heritage Areas joined the World Heritage List in 1985, and the first management plan was approved in 2011. With the annual revision processes of the management plans, in the context of the reconstruction process that is organized once every five years, the draft of the most recent management plan has been accepted in 2018. This study elaborates the Istanbul management plans of 2011 and 2018, particularly focusing on their preparation processes, the approaches embraced while making the plans, the influence of the plans on the protection of the Istanbul World Heritage Areas, and the perspectives of the local authorities and NonGovernmental Organizations "NGO's" regarding the plans.

Key Words: cultural heritage, world heritage area, management plan, historic peninsula, İstanbul.
\end{abstract}

\section{INTRODUCTION}

Today, along with the current discussions about integrated urban management strategies regarding values, management plans, protected areas, the development of responsible projects, renovation actions, and the financial mechanisms surrounding these actions, there are new concepts that play a significant role in urban protection and planning practices, such as "field management" and "management plans" for "World Heritage areas", which started to be debated in Turkey in the mid-2000s.

This study focuses on the term "management plan", which is one of the planning application tools that is accepted as a basis of the protection-usage, protection-development balance, and which was prepared for the first time for the Istanbul Historic Peninsula in 2011, as a requirement for the World Heritage Areas. According to the regulation, the management plan for the Historic Peninsula, which was approved in 2011, must be updated every five years. Once the plan had fulfilled its update process, the draft report was sent to UNESCO for evaluation in May 2018.

As the values requiring protection in the Historic Peninsula take up greater space in terms of surface area, compared to other examples in the world and as these values are not limited to the World Heritage areas, defining the borders of the Historic Peninsula's management plan and the location of this area in the Istanbul Metropolitan Area in the correct way is of 
major importance, both in determining the length of the management plan's preparation process and in comprehending the problems encountered in the application process.

\section{ISTANBUL AND THE HISTORIC PENINSULA}

As a transition between Anatolia and the Balkan Peninsula, at the conjunction point of the Asian and European continents, the borders of Istanbul consist of the Black Sea in the north, the steep hills of the Kocaeli Mountains in the east, the Sea of Marmara in the south, and the drainage divide in the Ergene Basin in the west, in terms of topography. The administrative borders, on the other hand, are determined as Kocaeli province in the east, and Tekirdag province in the west.

The Historic Peninsula that shapes the entrances of the Bosphorus and the Golden Horn in the Sea of Marmara, is surrounded by Eyup district in the north, Haliç and Beyoglu districts in the north east, the Sea of Marmara in the south, Zeytinburnu district in the west, and Bayrampaşa district in the north west (Fig. 1).

The Historic Peninsula is a geographic area where we witness the interaction between civilizations, as well as "cultural continuity" at an extremely impressive level. The city has been one of the rare urban settlements in which life has been sustained continuously for thousands of years. We also see that it has maintained its function as a capital for over 1500 years [1], [2].

The active role of the city as a "governing city" in such a large geography, and the history of significant artefacts that have been constructed, demolished and rebuilt in this context, contributed greatly in building up this accumulation. The political development process of the Historic Peninsula, as known today, started with the Byzantine city. It extended to the borders of today's Republic of Turkey, after having been positioned as an administrative centre in the Roman, Byzantine and Ottoman eras [3].

It is important to create a relationship between the "subregions" of the city. Istanbul, for instance, has spread across a large surface area (700 ha.), which tested the capacity of pedestrian walking in the 4th century AD. This situation required the construction of a highway system, allowing carriages to move around between cemeteries and monasteries, as well as through the city doors, scaffolds, trading regions, settlement areas, monumental open/closed service structures, palace, and the Acropolis of the ancient era (where governmental power and religious structures were concentrated in the city centre).

The present axis ( 25 meters wide) from the ancient city was renovated and became the main spine of "Mese", named after its location as "middle road", which is almost equidistant from the Sea of Marmara and the shores of the Golden Horn. At the entrance of Mese, Milion Monument and Hagia Irene ("Sacred Peace") Church (4th century AD) and, as another sovereign structure in the same space, Hagia Sophia Sanctuary ("Monument of Sacred Wisdom") (6th century AD) were constructed. The Mese axis united the Acropolis with the Magnum Palatium (Grand Palace), which was constructed in the 190s AD and is located on the slope, facing the Sea of Marmara next to the Hippodrome, with the subregions that were being developed on the western side of the city. Considering that the city expanded to its current surface area with Theodosius Land Walls (1600 ha) in the 5th century AD and that it surpassed the pedestrian walking capacity in the east-west direction, the importance of connecting the main axis to the function areas becomes clear: to provide settlement integration [4].

The Mese ceremony axis - towards the west - still exists in the shape of the standing stone that carries the name of Constantine, the Forum that shares the same name and Forum Tauri, which is ornamented with a victory tank. The axis then separates into two: The southern wing of Mese, which faces the Golden Door over Forum Bovis, and Forum Arcadius on the south 
crest of Lykos Hill, which faces the Sea of Marmara. The axis, following the crest that reaches toward the seventh hill of Istanbul from Forum Arcadius, finally reaches Romanum Gate (Topkapi). The northern wing of the Mese extends to the Gate of Adrianople (today, Edirnekapi) and to the holy springs in Kosmidion, with the mystical identity of the exterior parts of the city walls (today, Eyüpsultan), from the south of Blachernae and Tekfur Palaces, following the six hills of the peninsula that face the Golden Horn.

Afterwards, the Acropolis site, which is on the first hill that faces the Golden Horn, and which was later taken under the sovereignty of the Ottoman Empire, was fortified with Suri Sultani (Land Walls of Sultan). Then, Topkapi Palace (New Palace) was constructed as an inner castle for governmental work. The Topkapi Palace area, which was the governmental centre of the Ottoman Empire in the 16th and 17th centuries, also contained Enderun, where the governors were trained. The Imperial Edict of Gulhane, which represents the beginning of the Westernization process of the Ottoman system, was also declared in Gulhane Garden (today, Gulhane Park), which is located in the northern part of the governmental area. With the construction of Sur-i Sultani, the common area that Aya Sofia and the first court of Aya Irene Palace share, facing Mese road, was later ornamented with the Sultan III Ahmet Fountain.

Aya Sofia (Megale Eklesia) was reconstructed after the fires in the 5th and 6th centuries and transformed into a mosque later, in the Fatih period. It then evolved into a more impressive spectacle with the supporting structures and minarets that were implemented in the consolidation restoration of Sinan the Architect, following the damage that the building sustained during earthquakes. At the most impressive point of the historic core of Istanbul, seen from the directions of the Bosphorus, the Golden Horn, and the Sea of Marmara, with a magnificence that its location brings, Aya Sofia dominates as the "crown of the city", with views of the Bosphorus, the Anatolian Side, and the Sea of Marmara. Following the construction of Suleymaniye Social Complex, and other social complexes of the Sultans, especially with the accumulation of monumental buildings from the northern side of the Golden Horn, the Historic Peninsula (the inner part of the city walls) still preserves its role.

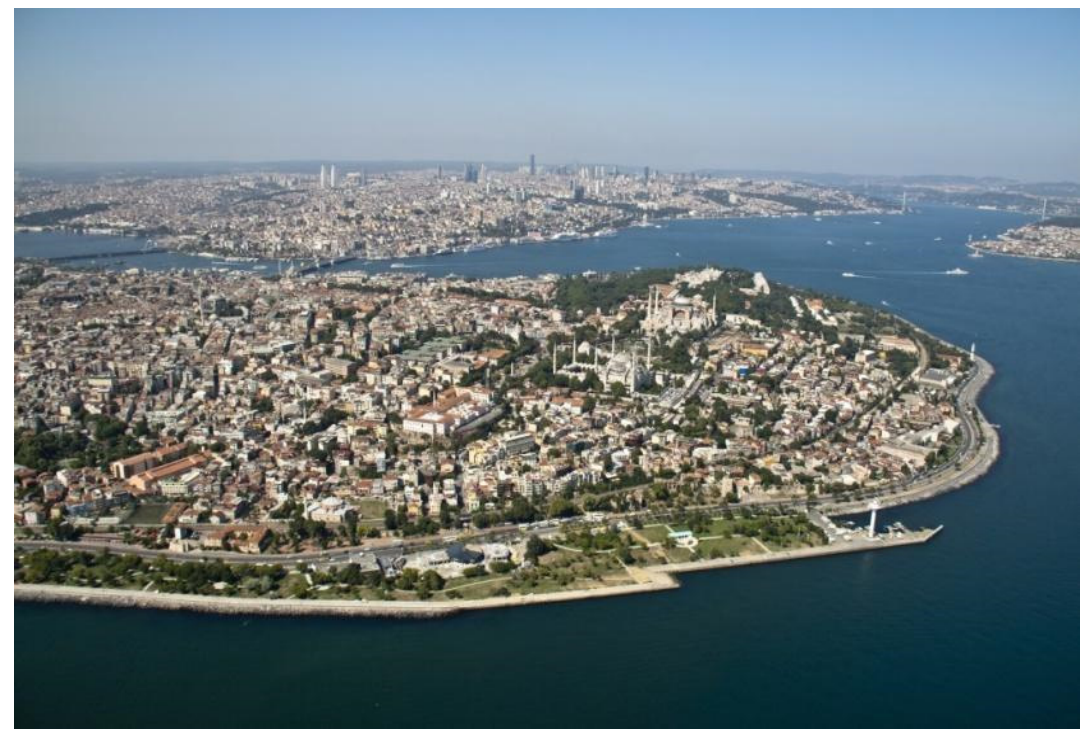

Figure 1: Historic Peninsula. 
Aya Sofia has been visited as a museum since the start of the Republican era. Aya Irene, which is in the court of Topkapi Palace, is a cultural structure in which concerts and music auditions are performed. The square in front of Aya Sofia and the Hippodrome (the Hippodrome and Sultanahmet Square after Sultan Ahmet Mosque was constructed), used to function as an assembly area, celebration centre, and an area for managing uprisings throughout history (see Fig. 2).

Cemberlitas (Column of Constantine), built upon the second hill, has encountered construction throughout time, with the circular forum (Forum of Constantine) in its associated area. The Mese axis, which has since been named as Divan Road / Ordu Street / Yeniceriler Street, owes its enlargement around Cemberlitas to this square. Bab-1 Ali (the government centre of the Ottoman era), located on a slope facing the Golden Horn, close to the trading centre of the capital city, maintained its existence even after the palace left the inner part of the land walls, and it continued to function as the Governor's Office after the start of the Republican era. The only embassy building (Iranian Embassy) that was allowed to be located inside Surici, as it belonged to a Muslim Country, was situated in this area. Banking buildings, the Grand Post Office, foundation halls, the Iranian Embassy, the Financial Office, and the Imperial Museum were located at the skirts of this hill and, in other words, in the government/trading region. Bab-1 Ali, as the press centre of Istanbul since the late-Ottoman period, is a location where printing houses mostly constituted the area usage, until Istanbul became decentralized from the historic city in the process of enlarging Istanbul to a metropolitan city. "Bab-1 Ali" has been associated with the publication of newspapers and magazines for long years in our country [5].

Suleymaniye Social Complex, which is located on the third hill, between two axes that face the Golden Horn shores, points to the urbanization condition and the architectural, aesthetic and artistic adequacy of the era, by possessing major magnificence on an urban scale and contributing to the silhouette of the Empire. It is also a building that constitutes the peak of the "unique" view of Istanbul.

The neighbourhoods of Suleymaniye district and Zeyrek district, which are located on two slopes of a hill that opens to the Golden Horn, still face each other over Ataturk Boulevard, which was constructed above this hill in the mid-20th century. The neighbourhoods of Suleymaniye and Sehzade Mosque, located in the south, can be observed from the pinnacles of wooden houses in Zeyrek and from the associated area of Pantocrator Church [6].

Forum Tauri, which is located on the southern part of the third hill, offered a space to many structures and witnessed various regulations throughout history, from the first palace (Old Palace) that was constructed in the Fatih Era, to Beyazit Social Complex that was built in the Sultan II Beyazit period, to the Seraskerat Institution, which was constituted in the reorganization of the Ottoman institutions, to Harbiye Jail, and to Istanbul University in the Republican period. Beyazit Square witnessed different social and cultural functions such as religious services, governmental and educational usage (madrasah, library), used-book bazaar, Cinaralti coffee house, open and closed meeting/assembly areas, and demonstrations. In order to develop the trading centre of the Ottoman capital, Bedesten was located to the north side (Golden Horn direction) of Forum Tauri (today, Beyazit Square), and bazaars such as Kapalicarsi (Grand Bazaar) were opened up in the associated area.

Thus, it is hard to find any other structures and settlements that are so continuous, intense, integrated and literally cosmopolitan, amongst heritage areas that are the subject of other management plans throughout the world.

Today, the real Istanbul, known as the "Historic Peninsula", creates a unique silhouette with its famous "Seven Hills" that form a chain by rising from an altitude of $45 \mathrm{~m}$ up to $85 \mathrm{~m}$, in the hill that elongates from Sarayburnu to Edirnekap1, with the monumental artefacts that 
are situated on these hills and on the inclined slopes to the Golden Horn, to the Sea of Marmara. The Land Walls that are an important symbol of the Historic Peninsula have been one of the basic spatial elements of the city throughout history. The harbours and infrastructure systems for providing water, which are some of the other structural factors of the city, began to be built in the Roman period and branched out with engineering applications in the Byzantine and Ottoman periods. Religious structures and public areas are shaped, based on the topography of the city, and the structural features are transformed under the light of socio-economic and cultural aspects that belong to different eras, while maintaining the continuity of the symbolic meaning [4].

\section{HISTORIC AREAS AND WORLD HERITAGE AREAS OF ISTANBUL}

The Convention Concerning the Protection of the World Cultural and Natural Heritage was approved in 1972, in the 17th General Conference of UNESCO (the United Nations Educational, Scientific and Cultural Organization). Turkey became a signatory to the World Heritage Convention in 1983. In 1985, Historic Areas of Istanbul, consisting of four regions, were included on the World Heritage List, which has been prepared by the World Heritage Committee since 1978. The regions included in the World Heritage List of UNESCO are Sultanahmet Urban and Archaeological Park, Süleymaniye Mosque and its Associated Conservation Area, Zeyrek Mosque (Pantocrator Church) and its Associated Conservation Area, and the Land Walls of Istanbul.

Historic Areas of Istanbul are included on the World Heritage List, since they meet "cultural criteria" (i), (ii), (iii), and (iv) of the ten criteria considered for including entities that possess outstanding universal value on the World Heritage List. These criteria are explained as (i) to represent a masterpiece of human creative genius; (ii) to exhibit an important interchange of human values, over a span of time or within a cultural area of the world, on developments in architecture or technology, monumental arts, town-planning or landscape design; (iii) to bear a unique or at least exceptional testimony to a cultural tradition or to a civilization which is living or which has disappeared; (iv) to be an outstanding example of a type of building, architectural or technological ensemble or landscape which illustrates (a) significant stage(s) in human history [7].

\subsection{Sultanahmet Urban and Archaeological Park}

Sultanahmet Urban and Archaeological Park, located in the east of the Historic Peninsula, on the first hill of Istanbul, consists of two different regions: Sur-i Sultani region, in which Topkapi Palace is situated, and Sultanahmet region. This region has been the centre of two great empires and civilizations. Sultanahmet Urban and Archaeological Park represents an area that possesses outstanding cultural and historical value in the Historic Peninsula, in terms of the monumental artefacts that it shelters today, above-ground residuals and underground artefacts, at the national and international level [8].

The number of cultural entities that are located inside the borders of the management plan sums a total of 10,151, of which 992 are situated in Sultanahmet Urban and Archaeological Park. Of these artefacts, $93 \%$ are protected on-site, and 7\% are not protected on-site, although their existence is known. The 992 registered artefacts in the area constitute $35 \%$ of the total 2,867 artefacts in all of the World Heritage Areas in Istanbul. Sultanahmet Urban and Archaeological Park is the heritage area in which the registered artefacts are mostly located. Monumental structures comprise 354 of the 992 artefacts in this area, of which 347 are present and seven are missing. Furthermore, there are 505 civil architecture examples in the area, 59 of them missing and 446 present [7]. 


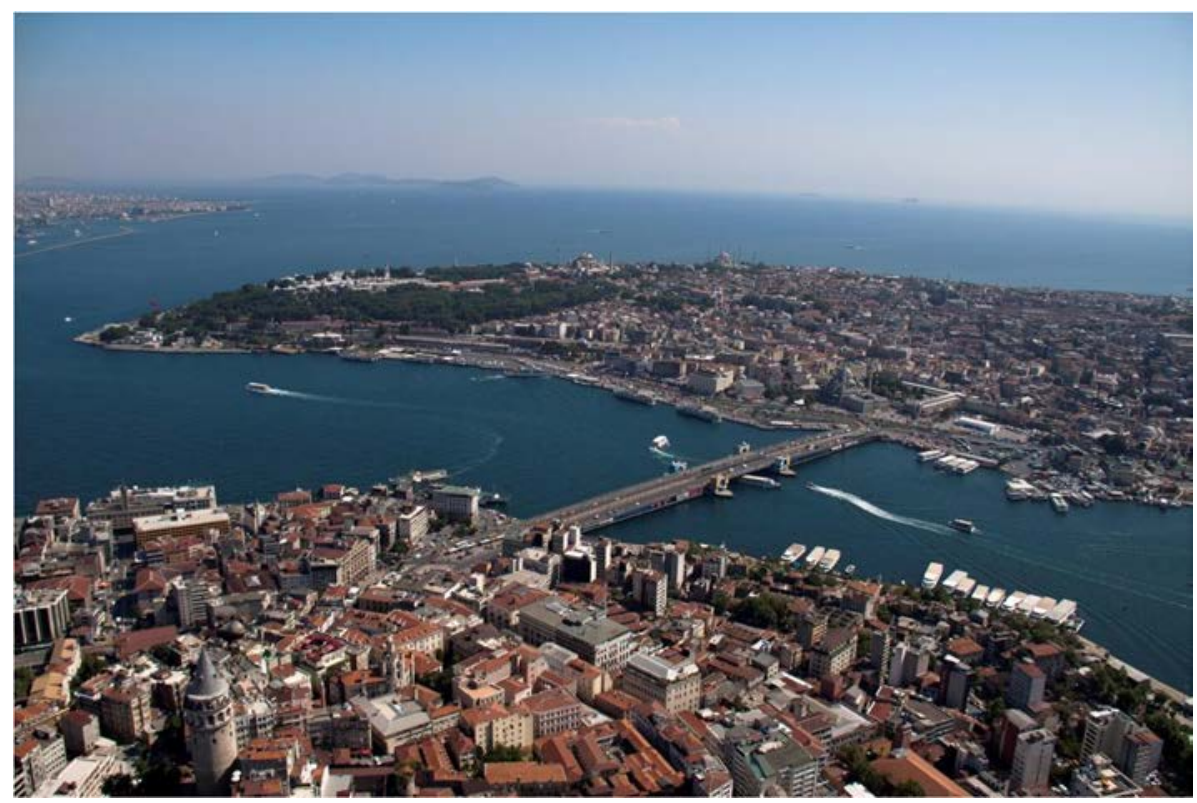

Figure 2: Golden Horn - Historic Peninsula.

\subsection{Suleymaniye Mosque and its Associated Conservation Area}

Suleymaniye Mosque and its Associated Conservation Area is situated on the slope of the third hill of Istanbul, in the north of the Historic Peninsula, facing the Golden Horn. It is situated between Ataturk Boulevard and Istanbul University in the east-west direction, and it extends towards the Golden Horn shore from Şehzade Complex. It takes its name from Suleymaniye Complex, located inside the borders of the area. The district shows the features of typical Ottoman-period settlements with traditional houses and neighbourhoods, composed of streets that protect their organic forms. The main component of the region is Suleymaniye Social Complex and its associated civil pattern.

In the decision to declare Suleymaniye Mosque and its Associated Area compatible with cultural criteria numbers (i), (ii), (iii), and (iv), and as one of the four heritage areas included on the World Heritage List under the name, "Historic Areas of Istanbul", Suleymaniye Mosque, which is the journeyman's craft of Sinan the Architect, was referenced, and it is underscored that 525 wooden houses are registered and under protection in this traditional settlement.

There are 920 registered artefacts in total in Suleymaniye Mosque and its Associated Conservation Area, 127 of which are missing and 793 present. Seven of the 358 monumental artefacts in the area are lost. The number of civil architecture examples are 515, of which 395 are present and 120 missing. Suleymaniye Mosque and its Associated Conservation Areas have two registered squares, differing from other heritage area components [7].

\subsection{Zeyrek Mosque (Pantocrator Church) and its Associated Area}

Zeyrek Mosque (Pantocrator Church) and its Associated Area is located on the fourth hill of Istanbul, surrounded by Ataturk Boulevard in the east. It is separated by Suleymaniye district 
(and Suleymaniye Mosque and Social Complex), which is another World Heritage Area located on another of Istanbul's hills. Fatih Mosque and Social Complex, which is one of the important buildings of the Historic Peninsula, is located in the west of the area. At approximately 10 hectares, Zeyrek Mosque (Pantocrator Church) and its Associated Conservation Area is the smallest heritage area, in terms of surface area, amongst Istanbul's other World Heritage Areas.

Zeyrek district, which is today known as the fourth hill of Istanbul, and which was known as the monastery region in the early part of the Byzantine period, still possesses the marks of the eras with its monumental buildings. The traditional pattern, consisting of wooden houses in rows, has protected its quality as a settlement area all along [9]. However, some incidents, such as fires, neglect and migration, have caused important destruction over time.

There are 234 cultural entities in total, 67 of which are missing. The total number of cultural entities in the area comprises almost $3 \%$ of the cultural entities in the management plan area in general and $10 \%$ of the total number of cultural entities in World Heritage areas in general. 55 of the cultural entities in the area were monumental artefacts and 179 were civil architectural examples. Of the monumental artefacts, 42 are present and 13 are lost; 125 of the civil architectural examples are present, and 54 are lost [7].

\subsection{Istanbul Land Walls Conservation Area}

Istanbul Land Walls Conservation Area extends from the Golden Horn to the Sea of Marmara in the north-south direction, at the western border of the Historic Peninsula, and consists of three main parts. These are defined as Wall Structure, Land Wall Interior Conservation Area, and Land Wall Exterior Conservation Area. There are 5,639 structures in total in the Istanbul Land Walls Conservation Area. Fifty-five of the 701 registered buildings are lost. The registered artefacts in the Istanbul Land Walls Conservation Area comprise 25\% of the registered artefacts in the World Heritage area in total and $7 \%$ of the registered artefacts in the management plan area in total. Of the 701 registered artefacts, 233 are monumental structures, 315 of which are civil architectural examples. Twenty of the lost 55 registered artefacts are monumental buildings, 28 are civil architectural examples, and seven are forbidden areas [7].

Considering the four criteria defined above regarding the World Heritage areas, the magnitude of the area, the management of the planning process, and the distribution of those institutions associated with the process, the distinction of the Historic Peninsula's management plan becomes apparent, compared to other management plans. Project packages, objectives and actions are determined by approaching the four heritage areas differently. However, the borders of the management plan are determined as the inner part of the city walls, including the buffer zone. During the preparation process of the plan, the authority also paid attention to the relation of the heritage sites with each other, their relation with the buffer zones, and with the monumental and civil architectural examples outside the heritage areas. The authority also showed regard to the unique patterns that need to be conserved in the area, and to the sustainability of World Heritage areas, and it also considered the surface area of the World Heritage areas.

In this context, the management plan area is 2,110 ha, the inner part of the city walls is 1,562 ha, and the buffer zone is $548 \mathrm{ha}$. Of 10,151 registered artefacts in the management plan area, 2867 (28\%) are located in heritage sites [4]. 


\section{RELATIONSHIP OF CONSERVATION PLAN TO MANAGEMENT PLAN}

As known, the management plan prepared for World Heritage areas is the roadmap that determines the conservation strategies of the areas that need to be protected, in the context of outstanding universal value, objectives, and actions. Furthermore, it guides those who are responsible for these actions. It also supports the application of the present conservation plan to the area. Moreover, as known, World Heritage areas have a protected area status that must be safeguarded by the government. Thus, before having a management plan, the aforementioned areas need to have a conservation plan [10], [11].

However, in October 2011, when the management plan for Istanbul's Historic Peninsula was approved, the conservation plan for the peninsula was at the preparatory stage. The conservation plan for the area was approved in December 2011 and the application plan in October 2012. Since there was no existent conservation plan at the time when the management plan was prepared, the actions in the management plan were defined in such a way that they would undertake the duty of the plan regarding application. Thus, the actions towards physical-spatial planning and/or physical-spatial intervention in the plan created a situation that overrode the authorities and the responsibility of Istanbul's Historic Site Manager, as well as the purpose of the management plan. Eliminating such project packages and actions from the management plans and making regulations that would be compatible with the decisions of the conservation plans were the first issues to be discussed in the updated process of the management plan.

In this context, 52 objectives, 86 strategies and 183 actions included in the Historic Peninsula's management plan, which was approved in 2011, were transformed into seven objectives, 18 strategies and 59 actions in the updated version of the plan in 2018. In this way, the structure became plainer, allowing the plan to be generated and supervised in short, mid and long terms [7].

In all these processes, the most important issue has been to provide a basis from which the awareness of the parties of the management plan could be raised, the management plan could be embraced, and local governments, NGOs, and professional chambers could play their part in protecting the World Heritage areas, as well as making them consider the conservation plans and management plans in the events that they would create.

\section{CONCLUSION}

Only 23 of 183 actions defined in the Istanbul Historic Peninsula Management Plan, approved in 2011, were accomplished. One of the most important reasons for this was the inability to define those responsible for the actions, since many of these actions affect the physical space. Another reason was the inability to find someone in charge, as well as the lack of a plan that would ensure the application of these actions. However, since this management plan was the first management plan, since it was conducted for the first time, and since it happened to be a fairly complex management plan, it is important for the parties to learn from the issue.

The most important outcome of the process to update the 2011 Historic Peninsula Management Plan was the meetings, workshops, and research conferences that were held repeatedly, with the participation of all associated parties, and also the importance of the management plan area. In this way, the significance of the management plan and the benefits of development based on plans were able to be transferred, told and explained to the parties on different platforms, and the associated institutions were encouraged to take responsibility and to obey the plan's decisions within a system. 
It is expected that the new management plan process will protect World Heritage areas, and that the decision-making process will become accelerated to preclude the determined threats.

\section{REFERENCES}

[1] Sakaoğlu, N., 8500 Yıllık Tarih İstanbul: Dünyanın En Eski Şehri, NTV Tarih, İstanbul, 2011.

[2] Tarihi Yarımada Koruma Amaçlı İmar Planı Açılama Raporu, İBB, pp. 45-51, 2011, https://www.ibb.gov.tr. Accessed on: 20 Jun. 2018.

[3] Yenen, Z., Social and religious influences on the form of early Turkish cities of the Ottoman Period. Journal of Architectural and Planning Research (JAPR). Special Issue: Influences on Urban Form, 9(4), pp. 301-314, 1992.

[4] Meriçboyu, Y.A., Çağlar Boyu İstanbul-İstanbul Arkeoloji Müzelerindeki Belgelerle İstanbul'un Tarihsel Gelişiminden Kesitler, Arkeoloji ve Sanat, 70, p. 11, 1996.

[5] Çelik, Z., 19.yy. da Osmanlı Başkenti: Değişen İstanbul 3, Tarih Vakfı Yurt Yayınları, Istanbul pp. 46-56, 2005.

[6] Stewig, R., Bizans Konstantinopolis, İstanbul "Dünya Şehri” Problemi Bakımından Bir Araştırma (Translation: Tufan, R., Yazman, M.S., Kiel 1964 issue), İstanbul Ticaret Odas1, Istanbul, 1965.

[7] Istanbul Tarihi Yarımada Yönetim Planı Taslak Raporu, İstanbul Sit Alanları Alan Başkanlığı, p. 76, 2018, https://www.alanbaskanligi.gov.tr/files/Y\%C3\%B6netim\%20 Plan\%C4\%B1_24\%C5\%9Fubat2012_k.pdf. Accessed on: 20 Jun. 2018.

[8] Ahunbay, Z., Sultanahmet Külliyesi, Dünden Bugüne İstanbul Ansiklopedisi, vol. 6, Kültür Bakanlığı ve Tarih Vakfı Ortak Yayını, pp. 55-61, 1994.

[9] Gülersoy-Zeren, N., Tezer, A., Yiğiter, R., Koramaz, T.K. \& Günay, Z., İstanbul Project: İstanbul Historic Peninsula Conservation Study, vol. 2 Zeyrek, UNESCOWorld Heritage Center, İstanbul Technical University Faculty of Architecture, ITU Environmental Planning and Research Center, 2008.

[10] Ringbeck, B., Management Plans for World Heritage Sites: A Practical Guide, German Commission For UNESCO, Bonn, 2008.

[11] Thomas, L., Middleton, J. \& Phillips, A., Guidelines for Management Planning of Protected Areas, World Commission on Protected Areas (WCPA), 2003, www.iucn.org/themes/wcpa/pubs/guidelines.html. Accessed on: 21 Feb. 2007. 